DOI 10.14746/ssp.2021.1.8

Dorota SZABAN

Uniwersytet Zielonogórski

ORCID: 0000-0001-5892-4095

Piotr MichaLAK

Badacz niezależny

ORCID: 0000-0003-4751-5100

\title{
„Wielka rzecz umieć czekać...”. Analiza sposobów realizacji polityki migracyjnej $w$ doświadczeniach tymczasowych migrantów zarobkowych z Ukrainy w Polsce w perspektywie neoinstytucjonalnej
}

Streszczenie: Sukces wdrożenia polityki migracyjnej zależy od wielu czynników, ale kluczową rolę w tym procesie odgrywają urzędnicy. Decyzje i projekcie migrantów dotyczące dalszego pobytu w Polsce zależą od interpretacji przepisów prawnych, reguł instytucjonalnych i formalnych w tym aspekcie. Celem artykułu jest analiza subiektywnych doświadczeń ukraińskich migrantów zarobkowych z polskimi instytucjami i reprezentującymi ich pracownikami. Nasze rozważania zostały umieszczone w paradygmacie neoinstytucjonalnym. Badanie subiektywnych interpretacji doświadczeń migrantów jest ważnym elementem analizy, który pozwoli nam sprawdzić, jak elementy polityki migracyjnej są wdrażane w praktyce. Biorąc pod uwagę ustalenia wynikające z badania, można założyć, że funkcjonowanie sprawnej administracji nie powinno ograniczać się tylko do zgodności z przepisami prawa, ale przekraczać je w granicach moralnie dozwolonych, w celu zwiększenia skuteczności realizowanych działań w wielu wymiarach.

Slowa kluczowe: neoinstytucjonalizm, polityka migracyjna, urzędnicy, badania jakościowe, migranci

\section{Wprowadzenie}

M igracje to fenomen społeczny, który posiada relatywnie sprawne mechanizmy adaptacyjne do zmian warunków politycznych, demograficznych i ekonomicznych. Międzypaństwowe przepływy pracowników tymczasowych mają fundamentalne znaczenie dla funkcjonowania rynków pracy. Relacja pomiędzy strumieniami migracji a rynkiem pracy 
ma charakter dwustronny. Z jednej strony przemieszczanie się ludności może samoistnie modyfikować rynki zatrudnienia ze względu na (nie) dostępność siły roboczej. Z drugiej strony - określona sytuacja na rynku pracy może wywoływać, czy stymulować poszczególne strumienie migracyjne (por. Migracje zagraniczne, 2008).

Mając na uwadze generowane przez zmiany w wielkości i strukturze populacji procesy społeczne państwa wypracowują polityki sektorowe $\mathrm{w}$ wielu obszarach powiązanych z rynkiem pracy. Jedną z takich polityk jest polityka migracyjna pozwalająca skutecznie zarządzać strumieniami migracji. Politykę migracyjną definiujemy na potrzeby tego opracowania szeroko - jako działania państwa dotyczące regulacji i kontroli wjazdu, pobytu oraz wyjazdu, a także warunków osiedlania się cudzoziemców w danym państwie i nadawania im obywatelstwa. Sytuacja taka dotyczy cudzoziemców, którzy emigrowali w celach zatrudnienia, bądź ochrony ze względów politycznych lub humanitarnych. Polityka migracyjna obejmuje swoim zasięgiem także zasady wyjazdu za granicę, powrotu i reintegracji własnych obywateli.

Polska ze względu na fakt, że przez dziesięciolecia miała charakter państwa emigracyjnego nie ma dużego doświadczenia w przyjmowaniu i integracji cudzoziemców. Zaczęli oni napływać do Polski po zmianie ustroju, a z nieco większym natężeniem po akcesji do Unii Europejskiej. Nie były to jednak ruchy masowe. Intensyfikacja procesów migracyjnych do Polski zaczęła się dopiero w 2014 roku, a ich główną przyczyną była intensyfikacja konfliktu we wschodniej Ukrainie. Polskie instytucje, zarówno publiczne, jak i społeczne w zróżnicowany sposób radzą sobie z cudzoziemcami, z ich potrzebami oraz z ich odmiennością kulturową. Obecność imigrantów w przestrzeni społecznej i publicznej wymusza ciągłe tworzenie i udoskonalanie reguł adaptacyjnych. Reguły te są szczególnie istotne w wymiarze formalnym, związanym z przyjmowaniem obcokrajowców i legalizacją ich pobytu w Polsce. W nawiązaniu do koncepcji „,paradygmatów polityki” Petera A. Halla warto przywołać ideę ,,społecznego uczenia się” polityk, czyli intencjonalnego dostosowywania ich kierunków i narzędzi do dotychczas posiadanych doświadczeń oraz ich zmiany zgodnie z napływającymi, nowymi informacjami (Hall, 1993). Dużą rolę w tym zakresie odgrywa doświadczenie i wiedza nabywana $\mathrm{z}$ dotychczasowego prowadzenia polityki, oraz dominująca rola administracji publicznej (urzędników jako głównego aktora realizacji danych polityk), a także jej względna autonomia wobec politycznych oczekiwań i społecznych wpływów. 
W niniejszym opracowaniu tematyka dotycząca mechanizmów radzenia sobie imigrantów z Ukrainy w obszarze formalnych procedur administracyjnych wpleciona została $\mathrm{w}$ analizy neoistytucjonalne. Instytucje mają zarówno charakter formalny przejawiający się w przepisach prawnych regulujących politykę migracyjną, jak i pozaformalny, przejawiający się w codziennych praktykach urzędników i imigrantów. Interakcje jednych i drugich osadzone w instytucjonalnych ramach przepisów i regulacji są silnie zdeterminowane społecznie, i jednocześnie przekładają się na konteksty społeczne, polityczne i ekonomiczne. Nie są to jednak relacje niezmienne. Zmieniają się one pod wpływem nabywanych doświadczeń, czasu i intensyfikującej się fali migracji (a także w wyniku zmian legislacyjnych, polityki wewnętrznej urzędów oraz oczekiwań samych imigrantów). Migracjami, ze względu na ich spontaniczny z natury charakter, nie jest więc łatwo sterować, szczególnie z wykorzystaniem zinstytucjonalizowanych narzędzi formalnych.

Perspektywa neoinstytucjonalna przyjęta w opracowaniu dotyczy przede wszystkim mechanizmów realizacji polityki migracyjnej. Mechanizmy te traktujemy jako ustrukturyzowany zestaw instrumentów, które służą rozwojowi społecznemu, poprzez tworzenie warunków sprzyjających legalnym migracjom zarobkowym do Polski i tworzeniu rozwiązań pojawiających się w tym obszarze problemów społecznych w intencjonalny sposób (Bekkers, Fenger, Scholten, 2017). Adresatem polityki migracyjnej na potrzeby niniejszego opracowania są imigranci dobrowolni, którzy przyjechali do Polski z Ukrainy na krótki czas, głównie w celach zarobkowych. Drugim aktorem (odniesieniem) analiz, jakiemu poświęcone jest to opracowanie są urzędnicy, przedstawiciele administracji publicznej, którzy w bezpośrednim często kontakcie z cudzoziemcami decydują o ich dalszym funkcjonowaniu w Polsce.

Celem przedstawionych rozważań jest analiza subiektywnych doświadczeń tymczasowych ukraińskich imigrantów zarobkowych z polskimi instytucjami i reprezentującym je personelem. Imigranci przybywający do nowego państwa zderzają się z nowym dla nich systemem działania państwa. Wyzwaniem jest poznanie reguł codziennego funkcjonowania w miejscu migracji, ale także sprostanie formalnym wymogom instytucjonalnym. Jednym z pierwszych kroków imigrantów jest zdobycie podstawowych informacji na temat zasad pobytu w nowym miejscu, przedłużania tego pobytu, a także odnajdowania się w systemie reguł i przepisów. W tym zakresie bardzo istotny jest kontakt i interakcje z urzędnikami - realizującymi te reguły formalne w praktyce. Strukturę 
publicznych służb zatrudnienia (powiatowe i wojewódzkie urzędy pracy) tworzą 354 urzędy, które obsługują 379 powiatów i 16 województw. Część zadań związanych z imigrantami wykonują urzędy wojewódzkie i ich filie. Jest to więc ponad 370 urzędów, które w zależności od stopnia ich zorganizowania na poziomie instytucjonalnym i operacyjnym w bardzo różny sposób realizują zadania wobec cudzoziemców. Ważnym elementem decydującym o wypełnianiu zapisów przepisów prawa przez urzędników jest także brak jednoznacznych interpretacji obowiązującego prawa (opisanego w kilku ustawach i rozporządzeniach) co prowadzi do różnych jego wykładni.

$\mathrm{W}$ opracowaniu poszukujemy odpowiedzi na pytanie o to $\mathrm{w}$ jaki sposób kształtuje się subiektywny stosunek imigrantów do urzędników wypełniających zapisy regulacji migracyjnych. Analiza subiektywnych doświadczeń imigrantów i ich interpretacji umożliwi nam sprawdzenie jak realizowane są elementy polityki migracyjnej „,w działaniu”. Interesuje nas ustalenie swoistego stopnia satysfakcji imigrantów z kontaktów z instytucjami (państwowymi i samorządowymi) odpowiedzialnymi za realizację rozproszonych zapisów polityki migracyjnej. Za najważniejsze elementy tej polityki - z punktu widzenia imigranta - należy uznać procedury związane z legalizacją pobytu i pracy w Polsce. Formułujemy założenie, że poziom satysfakcji wskazany przez imigrantów jest miarą skuteczności realizacji tych elementów polityki przez wszystkie instytucje odpowiedzialne za ich realizację. Rozproszenie kompetencji pomiędzy tak wiele urzędów w sytuacji niejednoznacznie brzmiących i rozumianych przepisów zarówno przez urzędników, jak i samych migrantów przekłada się na charakter postaw jednych wobec drugich. Społeczny odbiór postaw urzędników wobec imigrantów przekłada się także na ich postrzeganie państwa migracji i może przekładać się na dalsze plany migracyjne.

O jakości przepisów realizowanej polityki migracyjnej świadczy więc naszym zdaniem stopień, w jakim instytucje te są czytelne dla imigrantów i sposób, w jaki odbierany jest sposób realizacji przepisów przez urzędników. Odczytanie doświadczanych interakcji między urzędnikami pierwszego kontaktu a imigrantami pozwala ujawnić wpisane w ten obszar polityki publicznej niedoskonałości, sprzeczności i ukazać ich konsekwencje dla codziennego funkcjonowania tej kategorii społecznej.

Podstawą empiryczną dla naszych rozważań są wyniki badania jakościowego, realizowanego z wykorzystaniem wywiadów IDI wśród imigrantów zarobkowych z Ukrainy przebywających w Wielkopolsce. 
Badanie zrealizowano na przełomie 2019 i 2020 roku, uzyskując 36 rozbudowanych wywiadów.

\section{Teoria neoinstytucjonalna jako rama teoretyczna}

Paradygmat neoinstytucjonalny jest interdyscyplinarnym podejściem łączącym założenia analityczne wielu dyscyplin naukowych, w tym głównie ekonomii, nauk politycznych i socjologii (Sadowski, 2014, por. Skąpska, 1999). Poszukiwania badawcze przedstawicieli tego nurtu dotyczą z jednej strony diagnozowania możliwości i ograniczeń racjonalnej rekonstrukcji życia społecznego, z drugiej zaś odkrywania barier spontanicznego kreowania ładu społecznego. Rdzeniem tej koncepcji jest 'instytucja' (por. North, 1995). Termin ten odnosi się zazwyczaj do takich elementów naszego życia społecznego, które są częścią jego trwałej struktury, zespołów codziennych praktyk, jak i do bardziej sformalizowanych elementów naszego życia społecznego (North, 1991). W analizach neoinstytucjonalnych podkreśla się sprawczą rolę instytucji (Sadowski, 2014). Dzięki przeniesieniu odpowiedzialności na poziom instytucjonalny jednostki ponoszą mniejsze koszty transakcyjne niż gdyby zdecydowały się wejść w interakcję bez pomocy pośrednika. Instytucje mogą sprzyjać w uzyskiwaniu przez jednostki poczucia bezpieczeństwa i regularności. Jednostka jest traktowana jako poszukiwacz ładu i człowiek adaptujący się do poznawanych nowych reguł. Znaczącą koncepcję aktorów funkcjonujących w złożonej sferze instytucji sformułował Chmielewski (2011) jako homo agens-institutionalist. Homo agens-institutionalist zawsze działa w kontekście instytucji (ograniczeń formalnych i nieformalnych). Koncepcja ta zakłada, że ludzie są istotami, które, po pierwsze, są nierozerwalnie związane ze swoim społecznym otoczeniem, czyli instytucjami. Po drugie, są tych instytucji twórcami. Po trzecie zaś, tworzą te instytucje w sposób racjonalny, choć racjonalność ta zawsze ma charakter ograniczony. Instytucje i tworzony przez nie system reguł mają z natury charakter otwarty i zmienny, noszący znamiona „gry”. Taka konwencja teoretyczna pozwala poszerzyć granice znaczenia samego pojęcia o jej komponent behawioralny (por. Sadowski, 2014). Przyjmuje się, że uczestniczący w danej przestrzeni wymiany aktorzy posiadają swoje określone projekty działania, ale sposób ich realizacji jest wynikiem gry między nimi oraz często nieoczekiwanych efektów adaptacji do zastanych reguł (North, 1991). Dostosowanie społeczne do nieznanych dotąd reguł o charakterze formalnym często odbywa się z wykorzystaniem niefor- 
malnych sposobów działania. Odstępstwo od przyjętych zasad gry może przekładać się na praktyczną modyfikację dotychczasowego systemu reguł, albo zaprzestanie w niej uczestnictwa. Ważne jest, aby aktorzy, bazując na swojej podmiotowej sprawczości mogli dążyć do realizacji swoich strategicznych, przyjętych interesów. Można też przyjąć, że kiedy takie reguły zostaną utrwalone, może się zmienić charakter samych instytucji.

Ważnym elementem analiz neoinstytucjonalnych jest wyróżnianie określonych 'pól'. Pole jest efektem powielania określonych praktyk interakcyjnych do momentu, w którym następuje ich instytucjonalizacja (por. DiMaggio, 2006; Scott, 2014). W praktyce badawczej pole oznacza kontekst, w którym stosuje się reguły określonej instytucji. W niniejszym opracowaniu szczególną uwagę poświęcono polu organizacyjnemu polityki migracyjnej w Polsce. Aktorami tego pola są z jednej strony pracownicy instytucji i urzędów obsługujących migrantów, z drugiej zaś - sami imigranci.

\section{Polityka migracyjna - ogólne ramy legislacyjne}

Polityka migracyjna Polski realizowana była przez wiele lat w oparciu o wiele różnych regulacji, które nie zostały skodyfikowane w jednym dokumencie. Nie było w polskim systemie prawnym strategii dot. obszarów migracji, co zresztą charakteryzuje także inne obszary funkcjonowania sfery publicznej (Szymańska-Zybertowicz, 2011, s. 238; por. Chałupczak, 2013). Funkcjonowały jednakże rozmaite procedury legislacyjne regulujące kwestie mieszczące się w problematyce migracyjnej (por. Duszczyk, 2012). Rada Ministrów 31 lipca 2012 roku przyjęła dokument Polityka migracyjna Polski - stan obecny i postulowane działania, strategię określającą założenia polityki migracyjnej naszego państwa. W dokumencie zostały omówione wszystkie obszary polityki migracyjnej. Dyskusja wokół problemów migracji i zmian w zapisach polityki migracyjnej zintensyfikowała się po 2015 r., kiedy w tle kampanii wyborczej do parlamentu podejmowano decyzje dotyczące tzw. kryzysu uchodźczego. W 2016 r. anulowano obowiązujący dokument wyznaczający kierunki polityki migracyjnej, natomiast podjęto wysiłki w kierunku stworzenia nowej polityki migracyjnej. W 2017 r. rząd przyjął Strategię na rzecz Odpowiedzialnego Rozwoju do roku 2020 (z perspektywą do 2030 r.), w której zapowiedziano prace nad projektem strategicznym „Polityka migracyjna Polski”' (Strategia Odpowiedzialnego Rozwoju, 2017). Dokument określać ma priorytety społeczno-gospodarcze dla polskiej 
polityki migracyjnej, łączącej rozwiązania mające na celu minimalizowanie skutków zmian demograficznych i zaspokajanie potrzeb rynku pracy. W 2018 r. przyjęto dokument „Priorytety społeczno-gospodarcze polityki migracyjnej", opracowany pod kierunkiem Ministerstwa Inwestycji i Rozwoju i przyjęty przez Radę Ministrów. Zgodnie z zapisami dokumentu działania na rzecz migracji i migrantów powiązane być powinny z rozwojem społeczno-gospodarczym państwa przy jednoczesnym zapewnieniu odpowiednich standardów zatrudnienia i bezpieczeństwa. Jej ważnym celem jest uzupełnianie zasobów pracy kapitałem ludzkim spoza Polski, w branżach/zawodach, gdzie występują luki kompetencyjne, z uwzględnieniem ochrony krajowego rynku pracy, oraz na zachęcaniu do migracji powrotnych. Preferencje dotyczą osób, które mają polskie pochodzenie oraz potencjalną łatwość adaptacji wynikającą z posiadanego kapitału społecznego.

W 2019 r. powstał projekt dokumentu „Polityka migracyjna Polski”, jednak do dziś nie została ona przyjęta w procesie legislacyjnym (Polityka migracyjna Polski, projekt). W 2020 roku przystąpiono do prac nad nową polityką migracyjną kraju, zmieniając metodę postępowania stosowaną przy wcześniejszych pracach. Pojawienie się pandemii SARS-CoV-2 zahamowało proces powstawania polityki, ale Zespół ds. Migracji Departamentu Analiz i Polityki Migracyjnej MSWiA opracował dokument „Polityka migracyjna Polski-diagnoza stanu wyjściowego”, który wskazuje kluczowe problemy i ryzyka (Polityka migracyjna Polski - diagnoza stanu wyjściowego, 2020). Czy będzie on podstawą nowotworzonych regulacji pokaże czas.

Polska od kilku lat prowadzi aktywne działania w zakresie polityki migracyjnej wobec naszych wschodnich sąsiadów, w tym szczególnie wobec obywateli Ukrainy. Intensyfikujący się strumień migracji Ukraińców do Polski kształtuje się pod wpływem różnych czynników (szczególne znaczenie ma sytuacja polityczno-gospodarcza w Ukrainie na tle dobrej sytuacji ekonomicznej Polski). Zwiększoną mobilność kreuje także stosunkowo liberalne prawo migracyjne. Pracę w Polsce obywatele Ukrainy mogą podejmować na podstawie zezwolenia na pracę (typy A-E), przebywając na terenie RP na podstawie wizy, zezwolenia na pobyt rezydenta długoterminowego, zezwolenia na pobyt czasowy, wizy wydanej przez inne państwo obszaru Schengen, dokumentu pobytowego wydanego przez inne państwo obszaru Schengen lub w ramach ruchu bezwizowego. Kluczowym czynnikiem wpływającym na decyzje migracyjne obywateli ukraińskich była decyzja o liberalizacji systemu wizowego dla Ukrainy 
z dnia 11 maja 2017 roku. Natomiast 17 maja 2017 roku Parlament Europejski i Rada UE wydały stosowne rozporządzenie, zezwalające obywatelom m.in. Ukrainy na pobyt w strefie Schengen bez obowiązku posiadania wizy, na nie dłużej niż 90 dni w ciągu każdego 180-dniowego okresu (art. 1 ust. 2 Rozporządzenia Rady nr 539/2001). Te regulacje znacznie ułatwiły ruch migracyjny. Dodatkowo na mocy rozporządzenia z dnia 8 grudnia 2017 roku obywatele sześciu państw - Ukrainy, Rosji, Białorusi, Mołdawii, Armenii i Gruzji - korzystają z możliwości podjęcia zatrudnienia na podstawie: zezwoleń na pracę wydawanych przez wojewodów, zezwoleń na pracę sezonową ${ }^{1}$ wydawanych przez starostów w powiatowych urzędach pracy oraz oświadczeń o powierzeniu wykonywania pracy cudzoziemcowi, składanych przez pracodawcę w powiatowym urzędzie pracy (Rozporządzenie...). Cudzoziemcy mogą wykonywać pracę bez konieczności uzyskania zezwolenia na pracę pod warunkiem posiadania pisemnego oświadczenia podmiotu powierzającego wykonywanie pracy zarejestrowanego we właściwym powiatowym urzędzie pracy i pisemnej umowy przez okres 6 miesięcy w ciągu kolejnych 12 miesięcy. W sytuacji, gdy pracodawca chce zatrudnić cudzoziemca przez dłuższy okres czasu wymagane jest posiadanie zezwolenia na pracę albo zezwolenia na pobyt czasowy i pracę albo zezwolenia na pobyt czasowy w celu wykonywania pracy w zawodzie wymagającym wysokich kwalifikacji. Jeśli cudzoziemiec pracował u danego pracodawcy w związku z zarejestrowanym oświadczeniem, pracodawca ten może wystąpić o wydanie zezwolenia na pracę (na tym samym stanowisku) w trybie uproszczonym (bez konieczności uzyskania informacji starosty nt. możliwości zaspokojenia potrzeb kadrowych w oparciu o lokalny rynek pracy. Według danych Ministerstwa Rodziny, Pracy i Polityki Społecznej (Oświadczenia o powierzeniu wykonywania pracy cudzoziemcowi, wpisane do ewidencji oświadczeń, MRPiPS, 2020) w 2018 roku wydano w Polsce 1446304 oświadczeń o powierzeniu pracy obywatelom Ukrainy, a w 2019 roku - 1475923 (dotyczyły one 971840 Ukraińców), w 2020 takich oświad-

${ }^{1}$ Od 1 stycznia 2018 r. znowelizowana ustawa o promocji zatrudnienia i instytucjach rynku pracy wprowadza rozwiązanie umożliwiające zatrudnianie w Polsce cudzoziemców do pracy sezonowej - zezwolenie na pracę sezonową. Praca sezonowa to praca wykonywana przez okres nie dłuższy niż 9 miesięcy w roku kalendarzowym w sektorach: rolnictwo, ogrodnictwo, turystyka, w ramach działalności uznanych za sezonowe określonych w rozporządzeniu wykonawczym Ministra Rodziny Pracy i Polityki Społecznej w sprawie podklas działalności według klasyfikacji PKD, w których wydawane są zezwolenia na pracę sezonową cudzoziemca. 
czeń wydano 1329491 (dla 857622 Ukraińców). Wpływ na wielkość napływu imigrantów w 2020 r. miała pandemia koronawirusa SARS-Cov-2 i szereg restrykcji z nią związanych.

Przez ponad pół dekady liczba ukraińskich imigrantów w Polsce systematycznie rosła. Nie ma jednego kompleksowego źródła danych dotyczącego liczby Ukraińców przebywających w Polsce. System monitoringu oświadczeń i obowiązek rejestracji przez pracodawcę wykorzystywanego oświadczenia wprowadzony w 2018 r. wciąż nie pozwala na dokładną weryfikację liczby migrantów z Ukrainy w Polsce. Poszukuje się coraz to bardziej optymalnych narzędzi pomiaru skali zjawiska (por. Janicki, 2006). Według danych pochodzących z raportów firmy Selectivv w 2019 r. w Polsce przebywało 1,2 mln obywateli Ukrainy (Raport).

\section{Kluczowi aktorzy pola organizacyjnego polityki migracyjnej}

Dla potrzeb niniejszego artykułu istotna jest perspektywa pola organizacyjnego polityki migracyjnej, których rdzeniem są sformalizowane w dużej mierze regulacje prawne, kształtujące politykę migracyjną. Elementy polityki migracyjnej tworzone i odtwarzane są przez licznych aktorów, którzy współtworzą system znaczeń i mogą wzajemnie generować wiele sytuacji spornych (Scott, 2014, s. 106). Pole organizacyjne tworzą więc zarówno agendy reprezentujące władzę centralną, organizacje podległe samorządom lokalnym, organizacje pozarządowe, ale także reprezentacje organizacji międzynarodowych, organizacje migrantów, oraz instytucje badawcze (Pawlak, 2011; Pawlak, 2018).

Centralnym aktorem kształtującym politykę migracyjną w Polsce jest Minister Spraw Wewnętrznych i Administracji. Służby Ministerstwa nadzorują działania e-Departamentu Analiz i Polityki Migracyjnej, czy Straży Granicznej. MSWiA nadzoruje również działania urzędów wojewódzkich realizujących zadania związane z legalizacją pobytu cudzoziemców. Działania MSWiA są uzupełniane przez kompetencje Ministerstwa Rodziny, Pracy i Polityki Społecznej (w zakresie rynku pracy oraz procesów integracji społecznej) oraz Ministerstwo Spraw Zagranicznych (polityka wizowa), a także w niewielkim zakresie innych resortów rządowych (szkolnictwo wyższe, edukacja, zdrowie).

Na poziomie samorządowym politykę migracyjną realizują powiatowe urzędy pracy, odpowiadające za dokumentację związaną z krótkoterminowym zatrudnieniem cudzoziemców. Ważną rolę w systemie pełnią 
powiatowe centra pomocy rodzinie wspierające procesy jednostkowej integracji (szczególnie osób objętych międzynarodową ochroną). Ze względu na charakter współczesnych migracji i potrzebę wzmacniania procesów adaptacyjnych i integracyjnych coraz bardziej znaczącą rolę w kształtowaniu polityki migracyjnej przypisuje się włodarzom miast i gmin, które stają się centrum życia codziennego migrantów (por. Matusz-Protasiewicz, 2013). Kwestie migracyjne i dot. integracji cudzoziemców w ostatnich latach są coraz częściej podejmowane przez władze tych miast i gmin, które doświadczają migracji pracowniczej i jednocześnie tworzą swój wizerunek „miast otwartych”. Programy, projekty czy strategie migracyjne i integracyjne tworzone są często w sposób partycypacyjny, czyli przy współpracy organów samorządowych z organizacjami społecznymi i przedstawicieli społeczności akademickich. Organizacje pozarządowe uzupełniają działania rządowe i samorządowe wobec cudzoziemców, a także stanowią często ich audytorów. W tej kategorii szczególną rolę można przypisywać zarówno organizacjom pracodawców, organizacjom branżowym, jak i związkom zrzeszających migrantów - tej kwestii przypisuje się szczególnie dużą wagę.

W perspektywie mikrospołecznej, indywidualnej ogromne znaczenie mają codzienne relacje między cudzoziemcami (imigrantami) a przedstawicielami sfery publicznej, czyli głównie urzędników różnego szczebla. Sfera bezpośrednich kontaktów, codziennych interakcji na osi migranturzędnik to arena takich praktyk, które odbywają się w ramach instytucjonalnych i są regulowane organizacyjnie, ale mogą nabierać innego wymiaru wynikającego z relacji interpersonalnych (Sztandar-Sztanderska, 2016, s. 37). To jest obszar, gdzie najczęściej i w najbardziej intensywny sposób pojawia się asymetria aktorów. Rolę nadrzędną ma w tej relacji urzędnik. Połączenie interakcji społecznych z ładem prawnym intensyfikuje swoiste niedopasowanie posiadanych zasobów do potrzeb obydwu stron (por. Skowrońska, 2017).

\section{Urzędnicy jako szczególna kategoria aktorów pola organizacyjnego polityki migracyjnej}

Zazwyczaj pierwszym miejscem, z jakim mają do czynienia migranci, są urzędy. Sprawy, z którymi kierują się do nich cudzoziemcy, obejmują szeroki zakres udzielanych usług (sprawy meldunkowe, zawodowe, socjalne, zdrowotne, prawne itp.). Zasięg społecznej roli jest 
szeroki. Poprzez wypełnianie reguł przypisanych do zinstytucjonalizowanej roli socjalizują migrantów do ról społecznych (Sztandar-Sztanderska, 2016). Informują, jakie zachowanie jest „właściwe”, i jakie ciążą na danej osobie obowiązki i prawa. Jak podkreśla Dubois (2012, s. 84), ich praktyki są nieodzowną częścią ,trwającego wciąż procesu wytwarzania działania publicznego i mogą w nim odgrywać znaczącą rolę". Powtarzalne czynności urzędników konstytuują i pozwalają doświadczać politykę publiczną (por. Lipsky, 2010). Postrzeganie doświadczeń z urzędnikami przekłada się na stosunek migrantów do regulacji państwa, funkcjonowania sfery publicznej czy pośrednio również na uogólnione zaufanie społeczne.

Analiza doświadczeń imigrantów w kontaktach z urzędnikami wiąże się z koncepcją street-level bureaucracy, czyli nurtu skupiającego się na badaniu codziennego funkcjonowania instytucji publicznych (por. Lipsky, 2010). Takie podejście koncepcyjne umożliwia spojrzenie na politykę publiczną (tu: migracyjną) jak na praktyki społeczne, które urzeczywistniają ludzie działający w konkretnym miejscu i czasie (w otoczeniu reguł instytucjonalnych). W tym kontekście roli urzędników nie można sprowadzić do odtwarzania formalnych zaleceń, a raczej aktywnych współtwórców tej polityki. Otoczenie konkretnych instytucji, urzędów przekłada się na formalne wymogi ich działania, ale jednocześnie dają swoisty margines swobody działań - „dyskrecjonalność”. Urzędnicy mają możliwość pozostawania elastycznym i „grania” regułami (Sztandar-Sztanderska, 2016, s. 37). Decyzje urzędnicze decydują o dostępie do świadczeń, czy usług publicznych, determinując jednocześnie jakość życia imigrantów. W wielu obszarach polityki publicznej (politykę migracyjną również do niej zaliczamy) obserwujemy odchodzenie od modeli uniwersalnych świadczeń i zestandaryzowanych usług na rzecz usług realizowanych jako zoptymalizowane i dostosowane do potrzeb konkretnych grup czy kategorii społecznych.

\section{Podstawa empiryczna}

Podstawą empiryczną dla ustaleń zawartych w artykule są wyniki badania jakościowego, zrealizowanego z wykorzystaniem techniki wywiadu pogłębionego IDI, częściowo ustrukturyzowanego². W grudniu $2019 \mathrm{r}$.

${ }^{2}$ Badanie zostało zrealizowane w ramach projektu ,Strategie migracyjne ukraińskich migrantów zarobkowych w Polsce”, we współpracy Instytutu Socjologii Uni- 
i w styczniu 2020 r. zostało w ten sposób zrealizowanych 36 wywiadów wśród imigrantów z Ukrainy przebywających w Wielkopolsce (Poznań, Tulce, Murowana Goślina, Złotów, Swarzędz, Grodzisk Wielkopolski). Wywiady zrealizowane zostały z obywatelami Ukrainy przebywającymi w Polsce, zatrudnionymi w ramach różnego typu umów (głównie na czas określony), na zróżnicowany czas (głównie do 180 dni). Wywiady przeprowadzone były w języku ukraińskim, przez dwujęzyczne, przeszkolone realizatorki, a następnie tłumaczone na język polski. Zgromadzony materiał został przełożony na transkrypcje opatrzone komentarzami realizatorek wywiadów i zakodowany hierarchicznie według wyróżnionych wątków tematycznych. Jednym $\mathrm{z}$ wątków poruszanych w wywiadach były relacje z polskimi urzędami i urzędnikami badanych obywateli Ukrainy. Analiza zgromadzonego materiału została dokonana $\mathrm{z}$ wykorzystaniem technik CASQDAS - oprogramowania QDA Miner. Kwestie dotyczące doświadczeń instytucjonalnych i relacji z urzędnikami stanowiły jeden z wyróżnionych w scenariuszu bloków tematycznych, chociaż swobodne wypowiedzi w tym obszarze pojawiały się w wielu różnych częściach wywiadu, łącznie z projekcjami przyszłości migracyjnej.

\section{Postrzeganie urzędników przez migrantów}

Kontakt imigrantów z przedstawicielami instytucji publicznych jest zróżnicowany. Przekłada się on na subiektywne interpretacje sytuacji interakcyjnej na osi urzędnik-migrant, jaka sprzyja podejmowaniu przez migrantów zracjonalizowanych działań. Analiza wypowiedzi badanych pozwala odkryć w jaki sposób, subiektywnie konstruują oni role urzędnika i stosunek do niego i na tej podstawie mogą zachowywać się w określony sposób. Można wskazać trzy dominujące typy oceny tego kontaktu - pozytywny (promigrancki), negatywny (antymigrancki) i neutralny. Wyróżnione kategorie nie są jednak homogeniczne wewnętrznie.

Osoby, traktujące urzędników neutralnie, we własnych doświadczeniach podkreślają to, że zostały potraktowane tak, jak się można tego spodziewać w perspektywie instytucjonalnej - zgodnie z przyjętymi regułami publicznymi, gdzie migrant traktowany jest jako zwykły klient, obsługiwany poprawnie i efektywnie. Interakcje pomiędzy urzędnikami i imigrantami

wersytetu Zielonogórskiego i agencji pracy tymczasowej Work Glob sp. z o.o. z siedzibą w Poznaniu. 


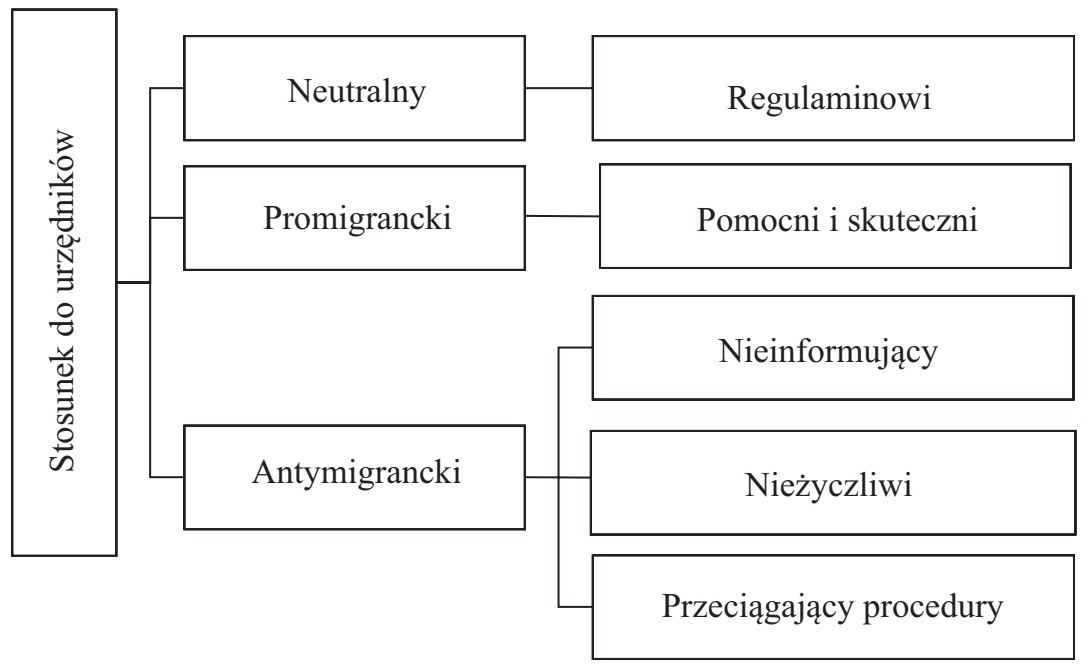

Rys. 1. Model postrzegania urzędników przez migrantów tymczasowych z Ukrainy

Źródło: Opracowanie własne.

w tym obszarze sprowadzają się do bezproblemowego załatwienia spraw, bez konieczności nakładania na tę relację jakiejkolwiek emocjonalnej kalki. Często jest to traktowane jako efekt powtarzających się sytuacji, które pozwalają na wykształcenie się odpowiednich sposobów działania.

„Dzisiaj byłem w inspekcji pracy to w ogóle nie odczułem żadnego problemu, że nie chcą pomagać. Tam, prawdopodobnie... po prostu zwracali się do mnie jak do osoby, która zwraca się z jakimś problemem. Nie zwracali uwagi na to, czy jestem Ukraińcem...". (10L)

„Nie miałem żadnych problemów. Już miałem pełny komplet dokumentów. Jeździłem do urzędu 3 razy. Po raz pierwszy oddałem wszystkie dokumenty. Po raz drugi złożyłem odciski palców. [...] Nie miałem problemów. Przyjeżdżałem już z oryginałami i kopiami. Oni wszystko sprawdzili, postawili pieczątki i powiedzieli «do widzenia». Nie było żadnych konfliktów. Wszystko miałem przygotowane. Urzędnicy widzieli, że mogłem odpowiedzieć na wszystkie pytania”. (I10)

„W tych sprawach, w których zwracałam się, wiedzieli, w jaki sposób mi pomóc. W moich przypadkach, było dobre przygotowanie". (I12) 
„Tak, kontaktowałem się z Urzędami 3 razy i zawsze udawało się wszystko załatwić [...] Dwa razy byłem osobiście, jeden raz elektronicznie. Nie, nie miałem problemów. Wszystko otrzymywałem, czego potrzebowałem. Wszyscy są kompetentni. Wszyscy znają swoje obowiązki. Wszystko było na wysokim poziomie". (I9)

„Z urzędami to w zasadzie tak..., w urzędzie oni są kompetentni, bo oni współpracują z obcokrajowcami i oni, no jakby już znają większość pytań, które zostaną im zadane, i oni już znają odpowiedzi na te pytania". (J7)

Dla innej kategorii imigrantów duże znaczenie ma pozytywny odbiór interakcji z urzędnikami. Część z badanych imigrantów swoje zadowolenie z kontaktów manifestuje poprzez wyrażanie wdzięczności urzędnikom za udzieloną pomoc. W wypowiedziach badanych pojawiają się elementy świadczące o tym, że interakcje z urzędnikami wykraczają poza zwykłą realizację założonych procedur, są oni życzliwi i potrafią zrozumieć trudną i często złożoną sytuację migrantów.

„W urzędzie mi bardzo pomogli, bo szybko te dokumenty zostały przerobione na nowo. Spodobało mi się, że nie trzeba było nic płacić i znów pomogły mi faktycznie pracownice urzędu. Oni zobaczyli, że zostałem oszukany i pomogli po prostu”. (10L)

Badani przyznają także, że interakcje pomiędzy nimi a urzędnikami nie są klasyfikowane jednoznacznie. Powoływanie się na doświadczenia własne, albo osób z bliskiego środowiska imigrantów pozwalają uznać, że w ich świadomości przyjazny stosunek urzędników, skuteczność ich pracy i wynikające z nich zadowolenia dotyczą jedynie części takich kontaktów i są traktowane jako wyjątek.

„No... czyli po równo jest dobrych i złych. Ale jeśli wziąć wagę skalę od 1 do 10 to gdzieś będzie 5. Pięć daję dobrym ludziom, ale nie złym". (J12)

„Są oczywiście fajne osoby, które chcą tobie pomóc i z nimi można się dogadać i oni nawet sami proponują tobie pomoc i nawet wypełniają zamiast ciebie dokumenty, jeśli widzą, że ty niepoprawnie wypełniasz i sami to robią. Cieszy mnie to, że tutaj są takie osoby, które odnoszą się do Ukraińców w taki sposób. Ale szkoda, że ich jest bardzo mało, większość tak sobie...” (J12)

Niezadowolenie przekładające się na negatywną ocenę relacji migrantów z urzędnikami jest z jednej strony wynikiem trudności w komunika- 
cji stron. Niedostateczna komunikacja i wynikające z niej niezrozumienie przekładają się na nieskuteczność realizacji zadań. Często jest to wynik bariery językowej.

„Tak były, ale były problemy przez barierę językową. Oni tak chcą ci pomóc i powiedzieć byleś ty ich zrozumiał, ale oni nie wiedzą jak do ciebie mówić. Mi było trochę łatwiej, ponieważ ja po Polsku trochę rozmawiam i nadal się go uczę". (1L)

„Nie, w urzędzie skarbowym nie udało się, oni nie rozumieli czego od nich chcę i nie starali się pomóc. Pomógł kolega męża, on jest Polakiem, on wytłumaczył, on powiedział jak wypełnić, jak wysłać dokument". (J9)

„....kiedy byłem w urzędzie $\mathrm{z}$ tymi papierami, dokumentami, chciałem, żeby je ulepszyli... nie chodzi o serwis, a stosunek do swojej pracy i żeby więcej i lepiej thumaczyli i pomagali jak radzić sobie z dokumentami, Ukraińcom mam na myśli, takim jak ja i innym. Żeby były dostępne po ukraińsku wszystkie dokumenty, żeby ktoś mógł zrozumieć jak to wypełnić, bo tam takiego czegoś nie ma. Ja z tym się spotkałem, chciałbym żeby oni poprawili, jak to się mówi, warunki do tego". (J10)

Niezadowolenie wynika także $\mathrm{z}$ braku dostatecznych informacji przekazywanych migrantom przez urzędników. To z kolei zmusza migrantów do działań, które w przyjętych przez nich schematach wykraczają poza oczekiwania w odniesieniu do kontaktów instytucjonalnych. Konieczność poszukiwania informacji na własną rękę wzmacnia niezadowolenie z pracy urzędników i przekłada się na negatywny stosunek do nich.

„Na drzwiach u nich napisane: «informacji nie udzielamy», podszedłem, spytałem - «my informacji nie udzielamy» tak ot, czy to dobre nastawienie do Ukraińców...?" (J5)

„Trochę udzielali, w większości to było tak ... dowiadywałem się przez internet oraz przez znajomych, którzy już pracowali, załatwiali karty pobytu. W zasadzie oceniam sytuację na 3, ponieważ bardzo długo oni to robią. I jeśli trzeba jakiś dokument, to oni później wzywają, by donieść, zamiast tego by od razu powiedzieć czego brakuje. Trochę tam skomplikowana sytuacja odnośnie tego." (L3)

„Ja spytałem gdzie, do którego pokoju mam się zwrócić by postawili stempel? «Idź Pan tam». Ale gdzie tam mam iść?, bo tam tych pokoi... więcej jak milion. Trafiłem, ze skutkiem na pół. Ale 
to nie to, że mi ktoś powiedział... Poszedłem, zacząłem otwierać kolejne drzwi, dopóki nie odnalazłem". (L5)

„Moim zdaniem, u nich ogólnie jest duży problem z przekazywaniem informacji. To stanowisko, gdzie zawsze jest kolejka z 1520 ludzi, gdzie musisz czekać przez 40 minut-godzinę, i gdzie w końcu zmęczona starsza Pani odpowie ci szybciutko w skrócie, żeby nie stracić dużo czasu... Już na tym etapie jest problem". (I5)

„W każdym urzędzie, do którego przyjdziesz oni z jednego na drugiego przekładają obowiązki i ty po prostu chodzisz i pukasz w drzwi i nie możesz znaleźć odpowiedzi. Zdarzają się po prostu takie przypadki, kiedy oni mają regulamin napisany, gdzie napisano, że oni obowiązują się wydać tobie konkretny dokument jeśli ty masz potwierdzający dokument i oni tobie odmawiają. Odmawiają bez wyjaśnień, po prostu odmawiają". (J12)

Negatywny stosunek do urzędników wynika także z doświadczeń migrantów, którzy przypisują urzędnikom nieżyczliwość i niewłaściwe ich traktowanie. Zdaniem badanych migrantów stosunek części urzędników jest nacechowany niemal dyskryminacyjnie. Przejawia się to nierównym traktowaniem, czego rezultatem jest często poczucie niższości osoby dyskryminowanej. Zachowanie dyskryminacyjne urzędników przejawia się wielorako, ale najczęściej zdaniem badanych przekłada się na nieprzyjemne relacje i nieskuteczność załatwiania spraw.

„No prawdopodobnie tak, są ludzie starej szkoły, którzy... po prostu widać, że człowiek nie lubi «chochołów» Ukraińców, dla niego nie ma różnicy czy to Rosjanin, czy to chochoł, są tacy ... może to pozostałość po czasach wojny". (L8)

„Wydaje mi się, że oni musieliby być trochę bardziej przyjaźni. Bo nawet, żeby wypełnić duży wniosek... I tam są takie rubryki... Nie uważam, że jestem głupia, ale nie wiedziałam, co mam tam napisać i jaka informacja tam musi być. I takiej informacji nigdzie nie znajdziesz, w jaki sposób ten wniosek musi być wypełniony. Przyszłam do urzędu i miałam kilka niewypełnionych kolumn. Miałam nadzieję, że tu mi pomogą wypełnić do końca. Ale urzędnik przez to był bardzo zirytowany. Rozumiem, że nie jestem jedną taką osobą i że dużo ludzi ma jakieś problemy. Ale to jest jego praca". (I5)

„Tak, żeby może ... traktowali milej Ukraińców, my w końcu, jak powiedzieć to dobrze? My w końcu wszyscy kiedyś gotowaliśmy 
się w jednej kaszy, my wszyscy jesteśmy Słowianami, i Polacy żyją niewiele lepiej niż Ukraińcy. [...] Żeby może trochę łatwiejsze było podejście do nas, jesteśmy Ukraińcami, tak rozumiem.... sama jestem z tych, którzy uważają że jeżeli ktoś przyjeżdża na Ukrainę i nie może mówić po ukraińsku kiedy przyszedł do sklepu, to mnie to denerwuje, przecież przyjechałeś do innego kraju". (J1)

„Ale duży problem jest by otrzymać kartę pobytu, albo to «wojewódzkie» ... ja nic nie mogę zaplanować, kiedy jechać do domu? Co robić? No jakby niewolnik, niewolnik w tym planie... poniżają moją godność, nie czuję się człowiekiem". (J3)

Dużym problemem dla migrantów jest czas oczekiwania na legalizację przedłużonego pobytu. Z wielu stron można usłyszeć głosy podkreślające przewlekłość postępowań prowadzonych przez urzędy w sprawach legalizacji pobytu cudzoziemców. Oczekiwanie na wydanie odpowiedniego zezwolenia na pobyt czasowy, pobyt stały lub na pobyt i pracę trwa po kilkanaście miesięcy. Generuje to problemy w codziennym funkcjonowaniu takich migrantów i wzmacnia poczucie braku życiowej stabilności. Z trudnościami i poważnymi ograniczeniami w dostępie do procedur legalizujących migranci mierzą się jeszcze przed wszczęciem procedury administracyjnej ze względu na charakter procedur. Ten obszar realizacji polityki migracyjnej w najbardziej odczuwalny sposób w relacjach migrantów przekłada się na ich postrzeganie instytucji i ich pracowników.

„Obecnie w urzędzie jest masakra. Za chwilę walczyć będą w urzędzie. Takie są warunki, że... Ukraińcy, Białorusi, Rosjanie, Chińczycy... będzie wojna za kolejkę. Ostatnio chciałem przynieść dodatkowe dokumenty, a tam były 3 kolejki. Nie wiedziałem, gdzie mam stać. Krótko mówiąc, bałagan. Jest dwóch, trzech dobrych urzędników, a inni po prostu nie chcą mieć z Ukraińcami nic do czynienia. Urząd to jest największy problem dla Ukraińców. Polacy powinni myśleć, jak ułatwić cały system. Wtedy będzie lepiej. Większość czeka na kartę pobytu półtora roku. Otrzymują karty, a za chwile muszą robić następne. Niektórzy nie wiedzą, że można zrobić oświadczenie, wrócić na Ukrainę i zrobić wizę i przyjechać ponownie. I muszą czekać półtora roku w Polsce. I to nigdy się nie skończy, dopóki nie zmienią procesu". (I11)

„Ja znam z doświadczenia u moich znajomych, kiedy bardzo długo czekali na «wojewódzkie» i robili dokumenty dla karty pobytu i na nie doczekali się, pojechali... no to żeby powiedzieć, że oni są bardzo zadowoleni z pracy urzędników to nie...” (J1) 
„Planowałem na stały pobyt się starać, ponieważ ze względu na polskie przepisy jeśli jestem specjalistą, a ja jestem specjalistą to mogę na stały pobyt za 2 lata papiery złożyć. Ale do tego muszę mieć kartę pobytu, ale oczywiście jej nie mam. Urząd musiał zrobić o wiele szybciej - 3 miesiące, ale w tej chwili już jest 1,5 roku i nie ma żadnych zmian. Urząd skarbowy również problemy. Oni nawet nie chcą słuchać o twoich problemach. Na przykład nie możesz dostać PESEL oraz innych rzeczy, ponieważ nie masz karty pobytu". (J12)

„Karty... oni i tak tam mają terminy, jeżeli się nie mylę, to od 4 do 8 miesięcy oni to produkują, póki urząd rozpatrzy i wszystko zrobi, ale przez to, że strumień ludzi jest duży to Urząd nie robi tego aż tak szybko. No i tam też tacy siedzą «nie przyniosłeś bo my zapomnieliśmy Ci o tym powiedzieć...» i ty nie przyniesiesz coś i do widzenia! Deportacja!" (J2)

\section{Podsumowanie}

Administracja powinna działać według jednolitych, spójnych procedur, w wyniku czego adresat takich usług może nauczyć się reguł funkcjonowania instytucji $\mathrm{w}$ danym obszarze. Według zinternacjonalizowanych reguł urzędnik jest traktowany neutralnie, jako pracownik administracji, który stosuje jednolitą interpretację przepisów w każdej sytuacji, jest kompetentny, ale jednocześnie bywa życzliwy i pomocny. W takim społecznym wyobrażeniu urzędnika, adresat jego działań traktowany jest jak mile widziany klient, a nie jak uciążliwy petent. W praktyce ten schemat niekoniecznie działa. Imigranci są specyficznym klientem instytucji i urzędów. Ta specyfika wynika przede wszystkim z faktu, że przebywając $\mathrm{w}$ Polsce krótko, nie znają procedur instytucjonalnych w pełni i na bazie koniecznych doświadczeń dopiero konstruują własną logikę tego typu interakcji. Ponadto często zmieniają się reguły prawne, kompetencje urzędów i urzędników są rozproszone, więc niestabilne stają się także zasady funkcjonowania instytucji. W tym kontekście przeprowadzone wywiady pokazały, że brak tej samej definicji i rozumienia przepisów dotyczących legalizacji pobytu i pracy cudzoziemców tworzy problemy na linii instytucja-imigrant. Obniża się bowiem efektywność realizowanych procesów - ergo generuje dodatkowe koszty po obu stronach oraz - co bardzo ważne - po stronie gospodarki/biznesu, który jest ostatecznie konsumentem pracy imigrantów zarobkowych w Polsce. Im 
dłużej trwają procedury, tym wyższy jest koszt legalizacji pobytu i pracy imigranta. Podobnie rzecz wygląda z perspektywy odpowiedzialności instytucji państwowych i samorządowych za obowiązki informacyjne i ich aktualizację - także w języku imigranta. Nadal do wyjątków należą te instytucje/urzędy, które ten obowiązek realizują w sposób adekwatny do dynamicznie zmieniającej się sytuacji prawnej.

W Polsce nie ma jednolitej i spójnej polityki migracyjnej, chociaż obowiązuje szereg przepisów regulujących choćby kwestie pobytu i zatrudniania cudzoziemców w Polsce. Realizacja zapisów tych dokumentów pozostaje w gestii wielu podmiotów, często powodując chaos kompetencyjny i trudności w ich odczytaniu przez imigrantów. W działaniu polityka migracyjna ma charakter procesualny, negocjowalny i wytwarzany właśnie w trakcie interakcji na linii urzędnik-migrant. Celem rozważań zawartych $\mathrm{w}$ artykule była rekonstrukcja subiektywnych doświadczeń tymczasowych ukraińskich imigrantów zarobkowych z polskimi instytucjami i reprezentującym je personelem. Nasze założenie/teza opiera się na stwierdzeniu, że poziom satysfakcji imigrantów z relacji z urzędnikami jest przejawem satysfakcji z działania procedur administracyjnych i realizacji złożonych przepisów prawa. W naszych rozważaniach postawy urzędników są konsekwencją konieczności realizowania zapisów legislacyjnych (niespójnych, niejednolitych i rozpraszających kompetencje) dotyczących funkcjonowania imigrantów w państwie przyjmującym. Społeczny odbiór postaw urzędników wobec imigrantów jednocześnie przekłada się na ich postrzeganie państwa migracji i może przekładać się na dalsze plany migracyjne.

Na podstawie wyników badania jakościowego, którego wyniki stanowiły postawę empiryczną dla podjętych rozważań możemy uznać, że obraz urzędnika nie jest konstruowany w opiniach migrantów w jednoznacznych kategoriach. Reguły instytucjonalnej gry w odniesieniu do realizacji polityki migracyjnej doświadczane przez migrantów pozwalają wskazać trzy ścieżki postrzegania urzędników - neutralną, pozytywną i negatywną. Nie można jednoznacznie określić jaka z postaw dominuje. Charakterystyka każdej z nich wskazuje obszary, którym warto się przyjrzeć próbując projektować zmiany w sposobach realizacji polityki. Kształtowanie dostosowanych do potrzeb odbiorców polityki migracyjnej procedur administracyjnych wymaga wypracowania takich reguł instytucjonalnej gry, które będą wykraczały poza dotychczas przyjęte schematy. Analizy z uwzględnieniem perspektywy neoinstytucjonalnej przekładają język obserwacji na język reguł, a więc pozwalają na wyciąganie wnio- 
sków dotyczących konkretnych układów norm i procedur. To szczególnie ważne w sytuacji rozproszenia kompetencji dotyczących imigrantów pomiędzy wiele urzędów. W praktyce imigrant ma do czynienia z urzędami pracy, urzędami wojewódzkimi, PIP, ZUS, US, Strażą Graniczną, a to nadal nie jest katalog zamknięty. Z przeprowadzonych wywiadów wyłania się obraz różnego poziomu wiedzy, kompetencji i roli urzędników reprezentujących różne instytucje w zakresie realizacji polityki imigracyjnej. To oznacza, że polityka wobec imigrantów jest realizowana na różnym poziomie efektywności w różnych instytucjach/urzędach.

Wyniki badania poza walorem czysto poznawczym, mogą okazać się przydatne dla praktyki społecznej, dostarczając wiedzy o tym, jak racjonalnie projektować innowacje społeczne, choćby w kontekście realizacji polityki migracyjnej. Mając na uwadze ustalenia wynikające z opracowania można przyjąć, że funkcjonowanie sprawnej administracji nie powinno być ograniczone jedynie do przestrzegania prawnych reguł, ale wykraczać poza nie w dozwolonych moralnie granicach, aby zwiększać skuteczność realizowanych działań. Urzędnicy korzystając z dostępnych zasobów powinni uzupełniać braki wiedzy dotyczące problematycznych kwestii dotyczących migrantów, powinni rozwijać swoją społeczną wrażliwość i nie dopuszczać do sytuacji, kiedy manifestują swoje uprzedzenia. Ich pracę powinny wspierać odpowiednie rozwiązania techniczne i prawne, związane chociażby z poprawą komunikacji z migrantami (tłumaczenia dokumentów, usługi tłumacza itd.). Zmiana reguł gry w realizacji polityki migracyjnej wymaga także zmian logiki migrantów. Pomocne w tym obszarze mogłyby okazać się informatory czy serwisy zawierające informacje o ścieżce postępowania w określonej sytuacji oraz zestaw odpowiedzi na najczęściej pojawiające się pytania.

\section{Bibliografia}

Bekkers V., Fenger M., Scholten P. (2017), Public Policy in Action: Perspectives on the Policy Process, Edward Elgar, Cheltenham.

Chałupczak H. (2013), Paradygmat badawczy polityki migracyjnej państwa z perspektywy politologicznej, w: Wspótczesne polskie migracje: strategie - skutki społeczne - reakcja państwa, red. M. Lesińska, M. Okólski, Wydawnictwa Uniwersytetu Warszawskiego, Warszawa.

Chmielewski P. (2011), Homo agens. Instytucjonalizm w naukach spotecznych, Akademia Leona Koźmińskiego, Poltext, Warszawa. 
DiMaggio P. (2006), Nowe spojrzenie na ,żelazna klatkę”: instytucjonalny izomorfizm i racjonalność zbiorowa w polach organizacyjnych, w: Współczesne teorie socjologiczne, tom I, red. A. Jasińska-Kania, L. M. Nijakowski, J. Szacki, M. Ziółkowski, Scholar, Warszawa.

Dubois V. (2009), Towards a critical policy ethnography: Lessons from fieldwork on welfare control in France, "Critical Policy Studies", nr 3(2), ss. 221-239.

Duszczyk M. (2012), Polska polityka imigracyjna a rynek pracy, Oficyna Wydawnicza ASPRA-JR, Warszawa.

Hall P. (1993), Policy Paradigms: Social Learning and the State. The Case of Economic Policymaking in Britain, "Comparative Politics", vol. 25, nr 3, ss. 275-296.

Janicki W. (2016), Wiarygodność danych o migracjach ludności w niektórych państwach Europy Zachodniej, „Wiadomości Statystyczne”, nr 3, ss. 80-92.

Lipsky M. (2010), Street Level Bureaucracy: Dilemmas of the Individual in Public Services, Russelll Sage Foundation, New York.

Matyja R., Siewierska-Chmaj A., Pędziwiatr K. (2015), Polska polityka migracyjna. W poszukiwaniu nowego modelu, Wydawnictwo Uniwersytetu Warszawskiego, Warszawa.

Migracje zagraniczne a procesy rynku pracy - przypadek Lubelszczyzny (2008), red. P. Kaczmarczyk, Warszawa-Lublin.

North D. C. (1991), Institutions, "Journal of Economic Perspectives", vol. 5, ss. 97-112.

North D. C. (1995), Institutions, Institutional Change and Economic Performance, Cambridge University Press, New York.

Oświadczenia o powierzeniu wykonywania pracy cudzoziemcowi, wpisane do ewidencji oświadczeń, MRPiPS (2020), https://psz.praca.gov.pl/web/urzad-pracy/-/8180211-oswiadczenia-o-powierzeniu-wykonywania-pracycudzoziemcowi-wpisane-do-ewidencji-oswiadczen-obowiazujace-od-2018-r, 18.02.2021.

Pawlak M. (2011), Termin ,integracja” jako narzędzie legitymizacji. Neoinstytucjonalna analiza uprawomocniania działań $w$ polu organizacyjnym obstugi i pomocy imigrantom w Polsce, "Studia Migracyjne - Przegląd Polonijny”, nr 37(2), ss. 59-80.

Pawlak M. (2018), Polityki publiczne wobec migracji, w: Nauki o polityce publicznej: Monografia dyscypliny, red. J. Kwaśniewski, Instytut Profilaktyki Społecznej i Resocjalizacji UW, Warszawa.

Polityka migracyjna Polski - diagnoza stanu wyjściowego (2020), Departament Analiz i Polityki Migracyjnej MSWiA, https://www.gov.pl/web/mswia/politykamigracyjna-polski--diagnoza-stanu-wyjsciowego, 18.02.2021.

Raport, https://selectivv.com/czy-ukraincy-wiaza-swoja-przyszlosc-z-naszym-krajem-najnowsze-badanie-selectivv/, 23.03.2020.

Rozporządzenie Ministra Rodziny, Pracy i Polityki Społecznej z dnia 8 grudnia 2017 r. w sprawie państw, do których obywateli stosuje się niektóre przepisy 
dotyczące zezwolenia na prace sezonowa oraz przepisy dotyczace oświadczenia o powierzeniu wykonywania pracy cudzoziemcowi, http://prawo.sejm.gov. pl/isap.nsf/DocDetails.xsp?id=WDU20170002349, 23.03.2020.

Sadowski I. (2014), Współczesne spojrzenie na instytucje. Ewolucja pojęć, problem modelu aktora i poziomy analizy instytucjonalnej, „Przegląd Socjologiczny”, t. 63, ss. 89-114.

Scott W. R. (2014), Institutions and Organizations: Ideas, Interests, and Identities, Sage, Los Angeles.

Skąpska G. (1999), Neoinstytucjonalizm, w: Encyklopedia socjologii, t. II, red. W. Kwaśniewicz i in., Oficyna Naukowa, Warszawa.

Skowrońska K. (2017), Niejednoznaczna władza, wspólne normy i niedopowiedziane cele: Działanie Wydziału Spraw Cudzoziemców Mazowieckiego Urzędu Wojewódzkiego jako studium przypadku pola organizacyjnego polityki migracyjnej w Polsce, „StudiaPolityczne”, nr 45(2), ss. 217-239.

Strategia Odpowiedzialnego Rozwoju (2017), Warszawa, https:/www.gov.pl/web/ fundusze-regiony/informacje-o-strategii-na-rzecz-odpowiedzialnego-rozwoju, 18.02.2021.

Sztandar-Sztanderska K. (2016), Obywatel spotyka państwo. O urzędach pracy jako biurokracji pierwszego kontaktu, Wydawnictwo Naukowe Scholar, Warszawa.

Sztandar-Sztanderska K. (2017), Czego nie widać? Literatura o polityce rynku pracy a praktyki urzędników pierwszego kontaktu, „Studia z Polityki Publicznej”, nr 2 (14), ss. 117-146.

Szymańska-Zybertowicz K. (2011), Nieobecne wyzwanie? Integracja jako zadanie polityki społecznej wobec cudzoziemców w Polsce po roku 1989, Wydawnictwo Naukowe Uniwersytetu Mikołaja Kopernika, Toruń.

Ustawa z dnia 20 kwietnia 2004 r. o promocji zatrudnienia i instytucjach rynku pracy, Dz. U. 2020.0.1409.

\section{"It is a great thing to be able to wait ...". The analysis of migration policy implementation in the experiences of temporary economic migrants from Ukraine in Poland in a neo-institutional perspective}

\section{Summary}

The success of migration policy implementation depends on many factors, but officials play a crucial role in this process. The decisions and projections of migrants considering their further stay in Poland depend on the interpretation of legal, institutional and formal regulations. The aim of the article is to analyze the subjective experiences of Ukrainian economic migrants with Polish institutions and the personnel representing them. Our considerations have been located within neo-institutional theory. Studying the subjective interpretations of migrants' experience is an important 
element of analysis that will allow us to check how the elements of migration policy are implemented in practice. Considering the findings resulting from the study, it can be assumed that the functioning of efficient administration should not be limited only to compliance with legal rules, but should go beyond them, within morally allowed limits, in order to increase the effectiveness of the activities carried out in various dimensions.

Key words: neo-institutionalism, migration policy, officials, qualitative research, migrants 
